\title{
Crystal and Molecular Structures of Three Pairs of Centrosymmetric, Square-Planar Tellurium(II) Complexes
}

\author{
Olav Foss, ${ }^{*}$ Knut Maartmann-Moe and Kjartan Marøy
}

Department of Chemistry, University of Bergen, N-5000 Bergen, Norway

\begin{abstract}
Foss, O., Maartmann-Moe, K. and Marøy, K., 1986. Crystal and Molecular Structures of Three Pairs of Centrosymmetric, Square-Planar Tellurium(II) Complexes. - Acta Chem. Scand. A 40: 685-694

The crystal structures of trans- $\mathrm{Te}(\mathrm{etu})_{2} \mathrm{Br}_{2}(1)$ and trans- $\mathrm{Te}(\mathrm{etu})_{2} \mathrm{I}_{2}(2)(\mathrm{etu}=$ ethylenethiourea), determined earlier, have been refined from MoK $\alpha$ diffractometer data, and the structures of $\left[\mathrm{Te}(\mathrm{etu})_{4}\right] \mathrm{Cl}_{2}(3),\left[\mathrm{Te}(\mathrm{esu})_{4}\right] \mathrm{Cl}_{2}(4)(\mathrm{esu}=$ ethyleneselenourea), trans-Te(tmtu) $)_{2}(\mathrm{SCN})_{2}(5)$ (tmtu = tetramethylthiourea) and trans-Te $(\mathrm{tmsu})_{2}(\mathrm{SeCN})_{2}(6)(\mathrm{tmsu}=$ tetramethylselenourea) have been determined and refined, to $R=0.025(1), 0.024(2), 0.021(3), 0.025(4), 0.028(5)$ and $0.041(6)$ for $1594,1730,3165,2819,2306$ and 1755 observed reflections, respectively. Complexes 1 and 2 are isomorphous, as are 3 and 4 , and 5 and 6 . The tellurium atoms lie in crystallographic symmetry centres. In the $\mathrm{TeS}_{2} \mathrm{X}_{2}$ groups of 1 and 2 bond lengths are Te-S 2.656(1) and 2.671(1) $\AA$ and Te-X 2.764(1) and 2.955(1) $\AA$ for $\mathrm{X}=\mathrm{Br}$ and $\mathrm{I}$, respectively. In the $\mathrm{TeS}_{4}$ or $\mathrm{TeSe}_{4}$ groups of complexes $3-6$ bond lengths are Te-S 2.666(1)-2.691(1) $\AA$ and Te-Se 2.773(1)-2.814(1) $\AA$. The two linear three-centre systems of a group deviate $0.81(2)-2.10(2)^{\circ}$ from orthogonality.
\end{abstract}

The crystal structures of the complexes trans$\mathrm{Te}(\mathrm{etu})_{2} \mathrm{Br}_{2}$ (1) and trans- $\mathrm{Te}(\mathrm{etu})_{2} \mathrm{I}_{2}$ (2) (etu = ethylenethiourea), based on X-ray film data, were reported some time ago. ${ }^{1}$ In order to make a survey of bond lengths in centrosymmetric tellurium(II) complexes ${ }^{2}$ more accurate data were of interest, and we report here refinements of the above two structures. We also report the structures of two pairs of complexes containing centrosymmetric $\mathrm{TeS}_{4}$ or $\mathrm{TeSe}_{4}$ coordination groups: $\left[\mathrm{Te}(\mathrm{etu})_{4}\right] \mathrm{Cl}_{2}(3)$ and $\left[\mathrm{Te}(\mathrm{esu})_{4}\right] \mathrm{Cl}_{2}(4)(\mathrm{esu}=$ ethyleneselenourea), trans- $\mathrm{Te}(\mathrm{tmtu})_{2}(\mathrm{SCN})_{2} \quad$ (5) (tmtu $=$ tetramethylthiourea) and trans$\mathrm{Te}(\mathrm{tmsu})_{2}(\mathrm{SeCN})_{2} \quad(6)$ (tmsu = tetramethylselenourea). Complexes 5 and 6 are isomorphous with trans- $\mathrm{Te}(\mathrm{tmtu})_{2}(\mathrm{SeCN})_{2} \cdot{ }^{3}$

\section{Experimental}

Preparations. The complexes $\mathrm{Te}(\mathrm{etu})_{2} \mathrm{Br}_{2}$, $\mathrm{Te}(\mathrm{etu})_{2} \mathrm{I}_{2}$ and $\left[\mathrm{Te}(\mathrm{etu})_{4}\right] \mathrm{Cl}_{2}$ were prepared as described previously. ${ }^{4,5}$ Well-developed crystals of the latter were obtained from a saturated, room temp. solution of the dihydrate ${ }^{5}$ in dimethylformamide by addition, with swirling, of an equal volume of concentrated $\mathrm{HCl}$.

The complex $\left[\mathrm{Te}(\mathrm{esu})_{4}\right] \mathrm{Cl}_{2}$ was prepared by dissolving $\mathrm{TeO}_{2}(0.40 \mathrm{~g})$ in hot concd. $\mathrm{HCl}\left(10 \mathrm{~cm}^{3}\right)$ and adding, with swirling, a warm solution of esu $(2.4 \mathrm{~g})$ in water $\left(40 \mathrm{~cm}^{3}\right)$. The mixture was filtered and allowed to cool, whereupon yellow crystals separated out. They were filtered off and washed with methanol containing a little $\mathrm{HCl}$, and then with diethyl ether; yield $1.4 \mathrm{~g}$ of yellow crystals $(70 \%$ based on $\mathrm{Te})$ Anal. $\mathrm{C}_{12} \mathrm{H}_{24} \mathrm{Cl}_{2} \mathrm{~N}_{8} \mathrm{Se}_{4} \mathrm{Te}: \mathrm{C}, \mathrm{H}, \mathrm{N}$. There was a tendency for the plate-like crystals to grow into composite prisms.

The complex $\mathrm{Te}(\mathrm{tmtu})_{2}(\mathrm{SCN})_{2}$ was prepared by adding a solution of $\mathrm{NH}_{4} \mathrm{SCN}(1 \mathrm{~g})$ in methanol $\left(10 \mathrm{~cm}^{3}\right)$ at room temp. to a mixture of $\mathrm{Te}(\mathrm{tmtu})_{2} \mathrm{Cl}_{2}^{2.6}(0.24 \mathrm{~g})$ and tmtu $(0.1 \mathrm{~g})$. On tri-

*'To whom correspondence should be addressed. 
FOSS ET AL.

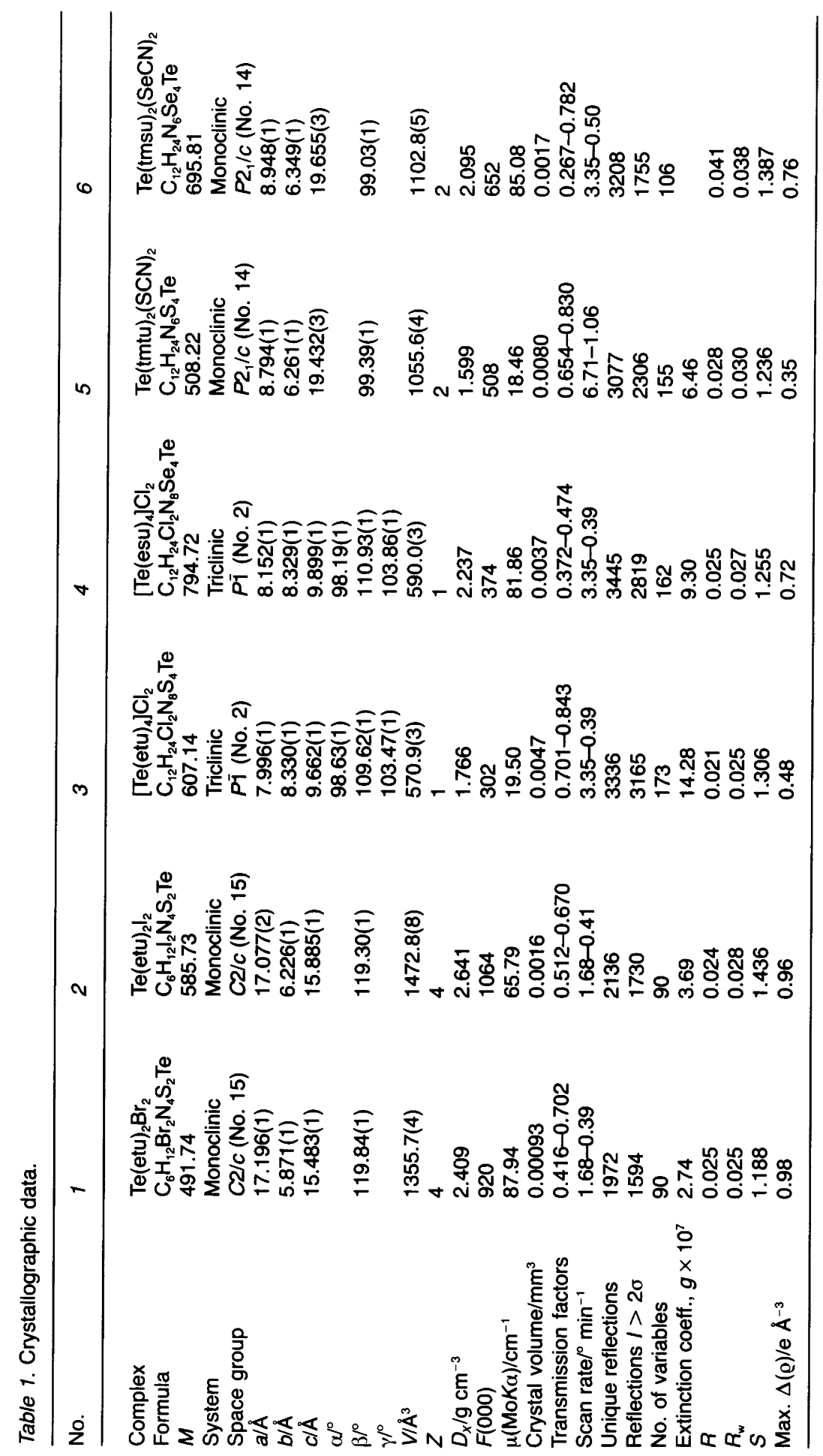


Table 2. Fractional atomic coordinates with e.s.d.s in parentheses.

\begin{tabular}{lllll}
\hline Atom & $x$ & $y$ & $z$ & $B_{\text {oq }} / \AA^{2}$ \\
\hline
\end{tabular}

$\mathrm{Te}(\mathrm{etu})_{2} \mathrm{Br}_{2}$

$\mathrm{Br}$

$S$

$\mathrm{N}(1)$

$\mathrm{N}(2)$

$\mathrm{C}(1)$

$\mathrm{C}(2)$

$\mathrm{C}(3)$

$\quad \frac{1}{4}$
$0.37769(2)$
$0.22201(5)$
$0.12640(15)$
$0.09972(15)$
$0.14700(16)$
$0.06187(20)$
$0.04393(18)$

$\mathrm{Te}(\mathrm{etu})_{2} \mathrm{I}_{2}$

$\mathrm{Te}$

I

$S$

$\mathrm{N}(1)$

$\mathrm{N}(2)$

$\mathrm{C}(1)$

$\mathrm{C}(2)$

$\mathrm{C}(3)$

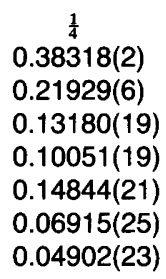

$\left[\mathrm{Te}(\mathrm{etu})_{4}\right] \mathrm{Cl}_{2}$

$\mathrm{Te}$

$S(1)$

$\mathrm{S}(2)$

$\mathrm{Cl}$

$\mathrm{N}(1)$

$\mathrm{N}(2)$

$\mathrm{N}(3)$

$\mathrm{N}(4)$

$\mathrm{C}(1)$

C(2)

$\mathrm{C}(3)$

$\mathrm{C}(4)$

$\mathrm{C}(5)$

$\mathrm{C}(6)$

0

$0.10692(6)$

$0.30179(6)$

$0.12332(6)$

0.20390 (24)

$0.23457(25)$

$0.39806(20)$

$0.61278(21)$

$0.18430(21)$

$0.44094(21)$

$0.26993(29)$

$0.28302(29)$

$0.54562(29)$

$0.70407(26)$

[Te(esu) $)_{4} \mathrm{Cl}_{2}$

\section{$\mathrm{Te}$}

$\mathrm{Se}(1)$

$\mathrm{Se}(2)$

$\mathrm{Cl}$

$\mathrm{N}(1)$

$\mathrm{N}(2)$

$\mathrm{N}(3)$

$\mathrm{N}(4)$

C(1)

$\mathrm{C}(2)$

$\mathrm{C}(3)$

$\mathrm{C}(4)$

$\mathrm{C}(5)$

$\mathrm{C}(6)$

$$
\begin{aligned}
& \multicolumn{1}{c}{0} \\
& 0.10301(4) \\
& 0.29896(4) \\
& 0.11975(10) \\
& 0.2089(4) \\
& 0.2339(4) \\
& 0.40302(30) \\
& 0.6190(3) \\
& 0.1873(3) \\
& 0.4478(3) \\
& 0.2719(4) \\
& 0.2814(5) \\
& 0.5473(4) \\
& 0.7072(4)
\end{aligned}
$$
$-0.07730(6)$
$0.30139(15)$
$-0.0915(5)$
$0.1025(5)$
$0.0939(5)$
$-0.2330(6)$
$-0.0987(7)$
$-0.08599(5)$
$0.30211(17)$
$-0.0800(6)$
$0.0999(6)$
$0.0987(6)$
$-0.2206(7)$
$-0.0964(7)$

$$
\begin{aligned}
& \multicolumn{1}{c}{0} \\
& 0.10721(2) \\
& 0.15282(5) \\
& 0.08450(16) \\
& 0.18545(17) \\
& 0.13914(18) \\
& 0.09477(24) \\
& 0.16694(22)
\end{aligned}
$$

2.282(5)

$3.689(7)$

3.05(2)

3.16(5)

$3.37(6)$

2.47(6)

$3.47(7)$

3.64(7)

2.458(6)

$3.579(5)$

$3.38(2)$

$3.81(7)$

$3.90(7)$

$2.83(7)$

3.99(9)

$3.89(8)$

2.305(3)

3.033(8)

3.330(9)

3.619(9)

$3.70(4)$

$3.78(4)$

$3.51(3)$

4.43(4)

$2.51(3)$

2.71(3)

3.72(4)

3.73(4)

4.06(5)

$4.18(5)$

$0.51094(27)$

$0.49417(26)$

$0.26123(24)$

$0.21357(25)$

2.288(5)

2.905(6)

$3.220(6)$

3.69(2)

$3.50(6)$

$3.53(6)$

3.32(6)

4.24(7)

2.43(5)

2.68(6)

$3.58(7)$

3.73(7)

$3.87(8)$

$4.02(8)$ 
FOSS ET AL.

Table 2. (contd)

\begin{tabular}{|c|c|c|c|c|}
\hline Atom & $x$ & $y$ & $z$ & $B_{\text {eq }} / \AA^{2}$ \\
\hline \multicolumn{5}{|c|}{$\mathrm{Te}(\mathrm{tmtu})_{2}(\mathrm{SCN})_{2}$} \\
\hline $\mathrm{Te}$ & 0 & 0 & 0 & $2.936(4)$ \\
\hline$S(1)$ & $-0.13019(10)$ & $0.36188(14)$ & $0.03644(5)$ & $4.68(2)$ \\
\hline$S(2)$ & $0.27506(9)$ & $0.10471(12)$ & $0.07470(4)$ & $3.92(1)$ \\
\hline$N(1)$ & $-0.2745(4)$ & $0.2199(6)$ & $0.14673(14)$ & $6.66(8)$ \\
\hline$N(2)$ & $0.2065(3)$ & $-0.1799(4)$ & $0.16860(11)$ & $3.78(5)$ \\
\hline$N(3)$ & $0.4330(3)$ & $-0.2345(4)$ & $0.12750(12)$ & $4.02(5)$ \\
\hline$C(1)$ & $-0.2155(4)$ & $0.2770(5)$ & $0.10166(15)$ & $4.57(7)$ \\
\hline$C(2)$ & $0.3064(3)$ & $-0.1187(5)$ & $0.12714(13)$ & $3.33(5)$ \\
\hline$C(3)$ & $0.0999(4)$ & $-0.0295(6)$ & $0.19236(16)$ & $5.36(8)$ \\
\hline$C(4)$ & $0.1741(4)$ & $-0.4028(6)$ & $0.18015(17)$ & $5.26(8)$ \\
\hline$C(5)$ & $0.5075(4)$ & $-0.3531(7)$ & $0.18895(19)$ & $6.15(9)$ \\
\hline$C(6)$ & $0.5225(4)$ & $-0.2291(7)$ & $0.06982(19)$ & $5.61(8)$ \\
\hline \multicolumn{5}{|c|}{$\mathrm{Te}(\mathrm{tmsu})_{2}(\mathrm{SeCN})_{2}$} \\
\hline $\mathrm{Te}$ & 0 & 0 & 0 & $3.30(1)$ \\
\hline $\operatorname{Se}(1)$ & $-0.13991(9)$ & $0.37482(13)$ & $0.03334(4)$ & $4.85(2)$ \\
\hline $\operatorname{Se}(2)$ & $0.28007(8)$ & $0.13051(12)$ & $0.07311(4)$ & $4.43(2)$ \\
\hline$N(1)$ & $-0.2794(8)$ & $0.2223(14)$ & $0.1504(3)$ & $7.3(2)$ \\
\hline$N(2)$ & $0.2069(6)$ & $-0.1642(9)$ & $0.1702(2)$ & $4.3(1)$ \\
\hline$N(3)$ & $0.4310(6)$ & $-0.2274(9)$ & $0.1320(3)$ & $4.5(1)$ \\
\hline$C(1)$ & $-0.2248(8)$ & $0.2807(12)$ & $0.1049(3)$ & $4.8(2)$ \\
\hline$C(2)$ & $0.3076(7)$ & $-0.1081(11)$ & $0.1297(3)$ & $3.9(1)$ \\
\hline$C(3)$ & $0.1020(9)$ & $-0.0128(15)$ & $0.1929(3)$ & $6.1(2)$ \\
\hline$C(4)$ & $0.1691(10)$ & $-0.3813(13)$ & $0.1816(3)$ & $5.6(2)$ \\
\hline$C(5)$ & $0.4979(10)$ & $-0.3522(14)$ & $0.1925(4)$ & $6.4(2)$ \\
\hline$C(6)$ & $0.5227(8)$ & $-0.2265(15)$ & $0.768(4)$ & $6.2(2)$ \\
\hline
\end{tabular}

turation a clear, orange solution was obtained and was placed in a freezer. The solution soon became grey and opaque and was filtered, and crystallization was initiated by seeding with $\mathrm{Te}(\mathrm{tmtu})_{2}(\mathrm{SeCN})_{2} .{ }^{3}$ After a few $\mathrm{h}$ in a refrigerator the crystals were filtered off and washed rapidly with a little freezer-cold ethanol and then diethyl ether; yield $0.17 \mathrm{~g}$ of yellow crystals (65\%). Anal. $\mathrm{C}_{12} \mathrm{H}_{24} \mathrm{~N}_{6} \mathrm{~S}_{4}$ Te: C, H, N, S.

The complex $\mathrm{Te}(\mathrm{tmsu})_{2}(\mathrm{SeCN})_{2}$ was prepared by triturating a mixture of $\mathrm{Te}(\mathrm{tmsu}) \mathrm{Cl}_{2}(0.37 \mathrm{~g})$ and tmsu $(0.4 \mathrm{~g})$ with warm methanol $\left(8 \mathrm{~cm}^{3}\right)$, and adding $\mathrm{KSeCN}(0.8 \mathrm{~g})$ and warm methanol $\left(7 \mathrm{~cm}^{3}\right)$. The mixture was rapidly heated and filtered, and the filtrate was allowed to cool, first to room temperature and then in a refrigerator. The crystals were filtered off and washed as above; yield $0.16 \mathrm{~g}$ of brownish-red crystals $(23 \%)$. Anal. $\mathrm{C}_{12} \mathrm{H}_{24} \mathrm{~N}_{6} \mathrm{Se}_{4} \mathrm{Te}: \mathrm{C}, \mathrm{H}, \mathrm{N}$.
The ligands esu and tmsu, prepared from etu or tmtu by the method of Klayman and co-workers, ${ }^{7}$ were a gift from Dr. O. Vikane. Te(tmsu) $\mathrm{Cl}_{2}$ was prepared from $\mathrm{TeO}_{2}, \mathrm{HCl}$ and tmsu by a procedure analogous to that for $\mathrm{Te}(\mathrm{tmtu}) \mathrm{Cl}_{2}{ }^{8}$

$X$-Ray structure analyses. Data were recorded on a CAD4 diffractometer using graphite-monochromated $\operatorname{Mo} K \alpha$ radiation $(\lambda=0.71069 \AA)$. Unit cell dimensions were determined from the diffractometer angles of 23-25 automatically centred reflections. Intensities out to $\theta=30^{\circ}$ were recorded using the $\omega$-scan mode, with a scan width of $1.00+0.35 \tan \theta$, plus $25 \%$ on each side for background. The intensities were corrected for Lorentz and polarization effects, decay and absorption. Maximum decay corrections, based on three reference reflections measured every $2 \mathrm{~h}$ of exposure time, were ca. $10,2,6,8,12$ and $19 \%$ for complexes $1-6$, respectively. Reflections 

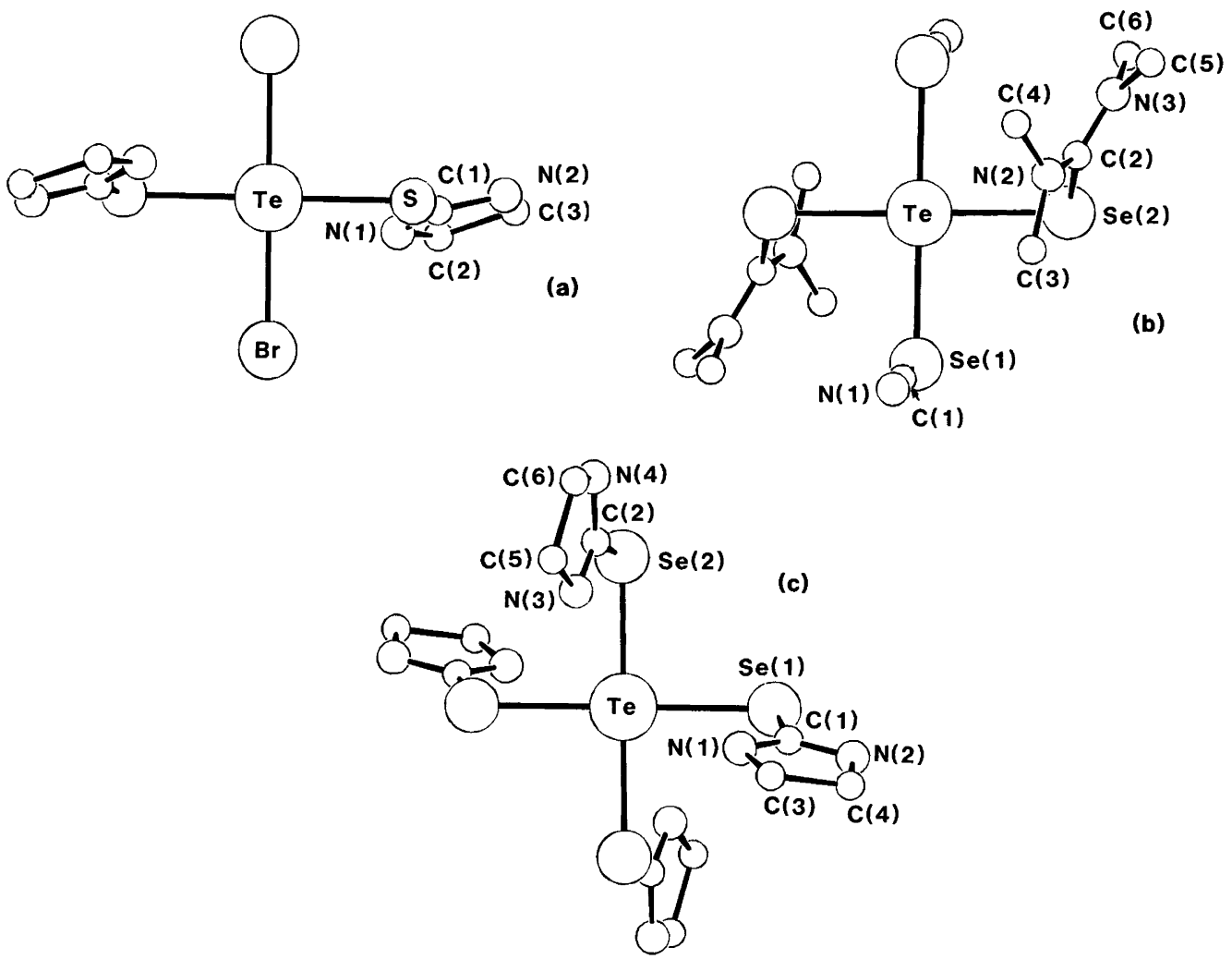

Fig. 1. Views of (a) the trans-Te(etu) $)_{2} \mathrm{Br}_{2}$ molecule, (b) the trans-Te(tmsu $)_{2}(\mathrm{SeCN})_{2}$ molecule and (c) the $\left[\mathrm{Te}(\mathrm{esu})_{4}\right]^{2+}$ ion in $\left[\mathrm{Te}(\mathrm{esu})_{4}\right] \mathrm{Cl}_{2}$, as seen normal to the coordination planes.

with $I>2 \sigma(I)$ were regarded as observed and were used in the calculations. These were carried out using the Enraf-Nonius SDP programs. Scattering factors, including anomalous dispersion terms, were taken from Ref. 9. Refinements were made by the full matrix least-squares method, the sum minimized being $\Sigma w \Delta^{2}(F)$ with $w^{-1}=\sigma^{2}(F)=\sigma^{2}(I) / 4 L p I$, and $\sigma^{2}(I)=\sigma^{2}(I)_{\text {count }}+$ $(0.02 I)^{2}$. Extinction corrections $F_{\text {corr }}=F_{\mathrm{c}}(1+$ $\left.g I_{\mathrm{c}}\right)^{-1}$ were applied and refined, except for complex 6. Anisotropic thermal parameters were used for all non-hydrogen atoms. The hydrogens of complexes 1-4 were first placed in calculated positions and those of 5 were located from a Fourier difference map; their positional and thermal parameters [common values of $\boldsymbol{B}_{\text {iso }}$ for the hydrogens of 1,2 and 4 and individual values for the hydrogens of 3 and 5] were then refined together with the other parameters. The final fractional hydrogen coordinates for complex 5 were entered for 6 and were held fixed, with a common fixed $B_{\text {iso. }}$.

Crystal data are given in Table 1. The structure of complex 4 was solved by Patterson and Fourier difference methods. Starting coordinates for complexes 1 and 2 were those derived previously, ${ }^{1}$ for 3 those for 4 , and for 5 and 6 those for the isomorphous $\mathrm{Te}(\mathrm{tmtu})_{2}(\mathrm{SeCN})_{2}{ }^{3}$ The parameter shifts in the last refinement cycles were less than one percent of the associated standard deviations. Atomic coordinates for non-hydrogen atoms are given in Table 2. Thermal parameters, hydrogen coordinates, torsion angles and planes have been deposited with the Cambridge Crystallographic Data Centre. 


\section{Results and discussion}

Bond lengths and angles are reported in Tables $3-5$, and views of one molecule or ion of each isomorphous pair are shown in Fig. 1.

The coordination groups. With the tellurium atoms in crystallographic centres of symmetry, the $\mathrm{TeS}_{2} \mathrm{X}_{2}, \mathrm{TeS}_{4}$ and $\mathrm{TeSe}_{4}$ coordination groups are exactly planar, and the two three-centre systems of each group are exactly linear. The angles between the two linear systems lie within $90 \pm$ $2.1^{\circ}$.

The refinements confirm the earlier structures ${ }^{1}$ of complexes 1 and 2 . The largest revision of any $\mathrm{Te}-\mathrm{S}, \mathrm{Te}-\mathrm{Br}$ or $\mathrm{Te}-\mathrm{I}$ bond length is for $\mathrm{Te}-\mathrm{S}$ in complex 1 , viz. from $2.686(15)$ to $2.656(1) \AA$. The bond lengths in the coordination groups are discussed elsewhere ${ }^{2}$ in relation to bond lengths in other centrosymmetric tellurium(II) complexes.

The ethylenethiourea and -selenourea ligands. The $\mathrm{SCN}_{2}$ or $\mathrm{SeCN}_{2}$ moieties are planar or nearly

Table 3. Distances $(\AA)$ and angles $\left(^{\circ}\right)$ in trans$\mathrm{Te}(\mathrm{etu})_{2} \mathrm{X}_{2}$ with e.s.d.s in parentheses. ${ }^{a}$

\begin{tabular}{lcc}
\hline & $X=B r$ & $X=1$ \\
\hline Bond lengths & & \\
Te-X & $2.764(1)$ & $2.955(1)$ \\
Te-S & $2.656(1)$ & $2.671(1)$ \\
S-C(1) & $1.709(3)$ & $1.704(3)$ \\
$\mathrm{C}(1)-\mathrm{N}(1)$ & $1.314(4)$ & $1.320(4)$ \\
$\mathrm{C}(1)-\mathrm{N}(2)$ & $1.326(3)$ & $1.321(4)$ \\
$\mathrm{N}(1)-\mathrm{C}(2)$ & $1.457(4)$ & $1.456(5)$ \\
$\mathrm{N}(2)-\mathrm{C}(3)$ & $1.457(5)$ & $1.456(5)$ \\
$\mathrm{C}(2)-\mathrm{C}(3)$ & $1.519(5)$ & $1.524(5)$ \\
Bond angles & & \\
$\mathrm{S}-\mathrm{Te}-\mathrm{X}$ & & \\
Te-S-C(1) & $89.19(2)$ & $89.15(2)$ \\
$\mathrm{S}-\mathrm{C}(1)-\mathrm{N}(1)$ & $105.60(10)$ & $105.23(10)$ \\
$\mathrm{S}-\mathrm{C}(1)-\mathrm{N}(2)$ & $128.0(2)$ & $128.0(2)$ \\
$\mathrm{N}(1)-\mathrm{C}(1)-\mathrm{N}(2)$ & $122.3(2)$ & $122.9(3)$ \\
$\mathrm{C}(1)-\mathrm{N}(1)-\mathrm{C}(2)$ & $109.8(3)$ & $109.2(3)$ \\
$\mathrm{C}(1)-\mathrm{N}(2)-\mathrm{C}(3)$ & $112.2(3)$ & $112.7(3)$ \\
$\mathrm{N}(1)-\mathrm{C}(2)-\mathrm{C}(3)$ & $112.6(3)$ & $113.2(3)$ \\
$\mathrm{N}(2)-\mathrm{C}(3)-\mathrm{C}(2)$ & $103.2(3)$ & $102.8(3)$ \\
\hline
\end{tabular}

aBond distances: $\mathrm{N}-\mathrm{H} 0.77(4)-0.88(5) \AA$ (mean 0.82 (2) $\AA$ ) , C-H 0.91(5)-1.06(4) $\AA$ (mean 0.98(1) $\AA$ ).
Table 4. Distances $(\AA \AA)$ and angles $\left({ }^{\circ}\right)$ in $\left[\mathrm{Te}(\mathrm{etu})_{4}\right] \mathrm{Cl}_{2}$ $(\mathrm{Y}=\mathrm{S})$ and $\left[\mathrm{Te}(\mathrm{esu})_{4}\right] \mathrm{Cl}_{2}(\mathrm{Y}=\mathrm{Se})$ with e.s.d.s in parentheses. ${ }^{a}$

$$
\mathrm{Y}=\mathrm{S} \quad \mathrm{Y}=\mathrm{Se}
$$

Bond lengths

$\begin{array}{lll}\text { Te-Y(1) } & 2.681(1) & 2.802(1) \\ \mathrm{Te}-\mathrm{Y}(2) & 2.666(1) & 2.773(1) \\ \mathrm{Y}(1)-\mathrm{C}(1) & 1.717(2) & 1.870(3) \\ \mathrm{Y}(2)-\mathrm{C}(2) & 1.714(2) & 1.859(3) \\ \mathrm{C}(1)-\mathrm{N}(1) & 1.315(2) & 1.312(3) \\ \mathrm{C}(1)-\mathrm{N}(2) & 1.316(2) & 1.315(3) \\ \mathrm{C}(2)-\mathrm{N}(3) & 1.312(2) & 1.321(3) \\ \mathrm{C}(2)-\mathrm{N}(4) & 1.325(2) & 1.322(4) \\ \mathrm{N}(1)-\mathrm{C}(3) & 1.456(2) & 1.455(4) \\ \mathrm{N}(2)-\mathrm{C}(4) & 1.459(2) & 1.461(4) \\ \mathrm{N}(3)-\mathrm{C}(5) & 1.455(2) & 1.455(4) \\ \mathrm{N}(4)-\mathrm{C}(6) & 1.455(3) & 1.458(5) \\ \mathrm{C}(3)-\mathrm{C}(4) & 1.529(3) & 1.527(4) \\ \mathrm{C}(5)-\mathrm{C}(6) & 1.514(3) & 1.514(5)\end{array}$

Bond angles

$\begin{array}{lcc}Y(1)-T e-Y(2) & 91.06(1) & 91.19(1) \\ \text { Te-Y(1)-C(1) } & 103.03(5) & 98.53(7) \\ \text { Te-Y(2)-C(2) } & 103.06(5) & 98.77(8) \\ Y(1)-C(1)-N(1) & 127.5(1) & 127.6(2) \\ Y(1)-C(1)-N(2) & 122.6(1) & 122.0(2) \\ N(1)-C(1)-N(2) & 109.9(2) & 110.4(2) \\ Y(2)-C(2)-N(3) & 127.6(1) & 127.1(2) \\ Y(2)-C(2)-N(4) & 123.2(1) & 123.6(2) \\ N(3)-C(2)-N(4) & 109.3(2) & 109.3(2) \\ C(1)-N(1)-C(3) & 112.7(1) & 112.3(2) \\ C(1)-N(2)-C(4) & 112.5(1) & 112.2(2) \\ C(2)-N(3)-C(5) & 112.6(2) & 112.4(3) \\ C(2)-N(4)-C(6) & 112.4(2) & 112.2(3) \\ N(1)-C(3)-C(4) & 102.4(1) & 102.7(2) \\ N(2)-C(4)-C(3) & 102.3(1) & 102.2(2) \\ N(3)-C(5)-C(6) & 102.6(2) & 102.4(3) \\ N(4)-C(6)-C(5) & 102.2(2) & 102.4(3)\end{array}$

aBond distances: $\mathrm{N}-\mathrm{H} 0.75(2)-0.80(2) \AA$ (mean 0.78 (1) $\AA$ ) , C-H 0.86(2)-1.03(2) $\AA$ (mean 0.94(2) $\AA$ ) for $\mathrm{Y}=\mathrm{S} ; \mathrm{N}-\mathrm{H} 0.69(4)-0.89(4) \AA$ (mean $0.79(5) \AA), \mathrm{C}-\mathrm{H}$ $0.84(4)-1.01(3) \AA$ (mean $0.92(2) \AA$ ) for $Y=S e$.

so. The two ethylene carbon atoms deviate significantly from the plane (see Table 6).

The mean dimensions of the four independent etu ligands, based on the values in Tables 3 and 4, are: S-C 1.713(3), C-N 1.318(2), N-C 1.456(1) and $\mathrm{C}-\mathrm{C} 1.522(4) \AA \AA \mathrm{A} ; \mathrm{S}-\mathrm{C}-\mathrm{N}(1)$ and $\mathrm{S}-\mathrm{C}-\mathrm{N}(3)$ 127.6(1), S-C-N(2) and S-C-N(4) 122.8(2), $\mathrm{N}-\mathrm{C}-\mathrm{N} 109.6(2), \mathrm{C}-\mathrm{N}-\mathrm{C} 112.6(1)$ and $\mathrm{N}-\mathrm{C}-\mathrm{C}$ 
$102.4(1)^{\circ}$. The two S-C-N angles in each ligand are distinctly different, and in each case the larger angle is associated with the nitrogen atom located closest to tellurium. The $\mathrm{Te} \cdot \mathrm{N}(1)$ distances are 3.608(3), 3.600(3), and 3.500(2) $\AA$ in complexes 1,2 , and 3 , respectively and the $\mathrm{Te} \cdot \mathrm{N}(3)$ distance is 3.489 (1) $\AA$ in 3. The hydrogen atoms bonded to these nitrogen atoms are

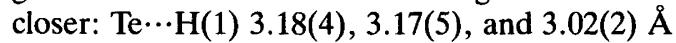
in complexes 1,2 and 3 , respectively, and $\mathrm{Te} \cdot \mathrm{H}(7) 2.97(2) \AA$ in 3 . In the esu ligands of complex 4 the $\mathrm{Se}-\mathrm{C}-\mathrm{N}$ angles are also different (see Table 4): $\mathrm{Te} \cdots \mathrm{N}(1)$ 3.544(2), $\mathrm{Te} \cdots \mathrm{N}(3) 3.516$

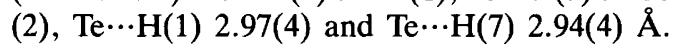
Repulsions possibly occur, thereby widening the angle.

In uncomplexed etu, ${ }^{10}$ the $\mathrm{S}-\mathrm{C}$ bond length is $1.688(3) \AA$, which is only slightly different from the mean bond length in the complexes. No structure determination for esu has been reported. In $\mathrm{PhTe}(\mathrm{esu}) \mathrm{Br},{ }^{11}$ the $\mathrm{Se}-\mathrm{C}$ bond length is 1.875(8) $\AA$, and in PhTe(esu)I, ${ }^{12} 1.866(7) \AA$.

The tetramethylthiourea and -selenourea ligands. The structures of four centrosymmetric trans$\mathrm{Te}(\mathrm{tmtu})_{2} \mathrm{X}_{2}$ complexes $[\mathrm{X}=\mathrm{Cl}, \mathrm{Br}$ or $\mathrm{I}$ (two forms)] have been reported elsewhere. ${ }^{2}$ Including the present complex 5 , the five structures contain eitht independent tmtu ligands, and we discuss these here.

The $\mathrm{SCN}_{2}$ moieties are planar within estimated error, their mean dimensions being $\mathrm{S}-\mathrm{C}$ 1.723(3) and $\mathrm{C}-\mathrm{N} 1.334(2) \AA, \mathrm{S}-\mathrm{C}-\mathrm{N} 121.9(1)$ and 119.5 $(2)^{\circ}$, and N-C-N 118.6(2) ${ }^{\circ}$. For tmtu itself, a gas phase electron diffraction study ${ }^{13}$ has yielded S-C 1.676(3) $\AA, C-N$ 1.388(5) $\AA$ and S-C-N 122.2 $(3)^{\circ}$, whilst the values from a single crystal X-ray study $^{14}$ are S-C 1.68(1), C-N 1.37(1) $\AA$ and S-C-N $119.6^{\circ}$. The S-C bond of tmtu thus lengthens on complexation, as noted earlier, ${ }^{15}$ and the $\mathrm{C}-\mathrm{N}$ bonds become shorter. As in the uncomplexed molecule ${ }^{13,14}$ and in other complexes, ${ }^{3,15,16}$ the methyl groups, for steric reasons, are rotated out of the $\mathrm{SCN}_{2}$ plane. The angles between the $\mathrm{SCN}_{2}$ plane and the $\mathrm{CN}\left(\mathrm{C}_{\mathrm{Me}}\right)_{2}$ leastsquares planes are $22.4-32.5^{\circ}$ (av. 27.6 ${ }^{\circ}$ ); this corresponds to angles of $47.5-51.9^{\circ}$ (av. $50.5^{\circ}$ ) between the two $\mathrm{CN}\left(\mathrm{C}_{\mathrm{Me}}\right)_{2}$ planes. The environment of the $\mathrm{N}$ atoms is not quite planar, the pyramid heights being $0.04-0.10 \AA$; their average of $0.08 \AA$ may be compared with $0.11 \AA$ in the free molecule. ${ }^{13}$
In tmsu crystals the $\mathrm{Se}-\mathrm{C}$ bond length is $1.836(4) \AA .{ }^{17}$ In complex 6 , at $1.872(6) \AA$, the bond is longer $[\Delta / \sigma(\Delta)=5.0]$.

The thio- and selenocyanate ligands. These are linear within estimated error. In the $\mathrm{SCN}^{-}$ion in $\mathrm{NaSCN}$ and $\mathrm{NH}_{4} \mathrm{SCN}^{18}$ the $\mathrm{S}-\mathrm{C}$ bond length is $1.648(1) \AA$, whereas for the covalently bonded $\mathrm{SCN}$ group in $\mathrm{CH}_{3} \mathrm{SCN}$ a value of 1.684 (3) $\AA$ has been found by microwave spectroscopy. ${ }^{19}$ The

Table 5. Distances $(\AA)$ and angles $\left({ }^{\circ}\right)$ with e.s.d.s in parentheses. $Y=S$ or Se: $Y(1)$ in SCN or SeCN ligand, $\mathrm{Y}(2)$ in tmtu or tmsu ligand. ${ }^{a}$

\begin{tabular}{ll}
\hline Te(tmtu $)_{2-}$ & $\begin{array}{l}\text { Te(tmsu })_{2-} \\
(\mathrm{SeCN})_{2}\end{array}$ \\
\hline
\end{tabular}

\section{Bond lengths}

$\begin{array}{lll}\mathrm{Te}-\mathrm{Y}(1) & 2.685(1) & 2.814(1) \\ \mathrm{Te}-\mathrm{Y}(2) & 2.691(1) & 2.811(1) \\ \mathrm{Y}(1)-\mathrm{C}(1) & 1.662(4) & 1.802(7) \\ \mathrm{C}(1)-\mathrm{N}(1) & 1.146(4) & 1.145(8) \\ \mathrm{Y}(2)-\mathrm{C}(2) & 1.726(3) & 1.872(6) \\ \mathrm{C}(2)-\mathrm{N}(2) & 1.341(3) & 1.341(7) \\ \mathrm{C}(2)-\mathrm{N}(3) & 1.328(3) & 1.334(7) \\ \mathrm{N}(2)-\mathrm{C}(3) & 1.456(4) & 1.462(8) \\ \mathrm{N}(2)-\mathrm{C}(4) & 1.449(4) & 1.445(8) \\ \mathrm{N}(3)-\mathrm{C}(5) & 1.467(4) & 1.475(8) \\ \mathrm{N}(3)-\mathrm{C}(6) & 1.471(4) & 1.459(7)\end{array}$

\section{Bond angles}

$\begin{array}{lcc}Y(1)-T e-Y(2) & 92.10(2) & 91.45(2) \\ \mathrm{Te}-\mathrm{Y}(1)-\mathrm{C}(1) & 101.32(11) & 99.13(21) \\ \mathrm{Y}(1)-\mathrm{C}(1)-\mathrm{N}(1) & 179.6(3) & 179.5(6) \\ \mathrm{Te}-\mathrm{Y}(2)-\mathrm{C}(2) & 99.43(9) & 95.09(18) \\ \mathrm{Y}(2)-\mathrm{C}(2)-\mathrm{N}(2) & 121.9(2) & 122.0(4) \\ \mathrm{Y}(2)-\mathrm{C}(2)-\mathrm{N}(3) & 119.9(2) & 120.7(4) \\ \mathrm{N}(2)-\mathrm{C}(2)-\mathrm{N}(3) & 118.2(2) & 117.3(6) \\ \mathrm{C}(2)-\mathrm{N}(2)-\mathrm{C}(3) & 121.6(3) & 122.0(6) \\ \mathrm{C}(2)-\mathrm{N}(2)-\mathrm{C}(4) & 122.2(3) & 122.8(5) \\ \mathrm{C}(3)-\mathrm{N}(2)-\mathrm{C}(4) & 114.9(3) & 113.7(6) \\ \mathrm{C}(2)-\mathrm{N}(3)-\mathrm{C}(5) & 122.9(3) & 124.2(5) \\ \mathrm{C}(2)-\mathrm{N}(3)-\mathrm{C}(6) & 122.4(3) & 122.1(5) \\ \mathrm{C}(5)-\mathrm{N}(3)-\mathrm{C}(6) & 114.1(3) & 113.4(5)\end{array}$

\section{Non-bonded contacts}

$\begin{array}{lll}Y(2) \cdots C(3) & 3.075(4) & 3.175(6) \\ Y(2) \cdots C(6) & 3.029(4) & 3.131(7) \\ \mathrm{C}(4) \cdots \mathrm{C}(5) & 2.925(7) & 2.923(11) \\ \mathrm{Te} \cdots \mathrm{C}(3) & 3.702(4) & 3.758(6)\end{array}$

a'Bond distances: in complex 5, C-H 0.89(3)-1.03(4) $\AA$ (mean $0.96(2) \AA$ ); in 6 , with $\mathrm{H}$ coordinates from 5 , C-H 0.85-1.14 $\AA$ (av. 0.99 $\AA$ ). 
Table 6. Planes of portions of the molecules.

trans- $\mathrm{Te}(\mathrm{etu})_{2} \mathrm{X}_{2}$

Plane (1): Te, $S, X$

Plane (2): Te, S, C(1)

Plane (3): $S, C(1), N(1), N(2)$

$$
\mathrm{X}=\mathrm{Br} \quad \mathrm{X}=\mathrm{I}
$$

Angles $\left({ }^{\circ}\right)$ between planes

$\begin{array}{lll}(1)-(2) & 84.5 & 80.3 \\ (1)-(3) & 80.0 & 76.2 \\ (2)-(3) & 18.0 & 17.5\end{array}$

Distances $(\AA)$ of carbon atoms from thiourea plane (3) ${ }^{a}$

\begin{tabular}{lrr}
$C(1)$ & $0.000(3)$ & $0.001(3)$ \\
$C(2)$ & $-0.055(3)$ & $-0.040(4)$ \\
$C(3)$ & $-0.076(3)$ & $-0.081(4)$ \\
\hline
\end{tabular}

$\left[\mathrm{Te}(\mathrm{etu})_{4}\right] \mathrm{Cl}_{2}$ and $\left[\mathrm{Te}(\mathrm{esu})_{4}\right] \mathrm{Cl}_{2}{ }^{b}$

Plane (1): Te, $Y(1), Y(2)$

Plane (2): Te, $Y(1), C(1)$ or $\mathrm{Te}, \mathrm{Y}(2), \mathrm{C}(2)$

Plane (3): $Y(1), C(1), N(1), N(2)$ or $Y(2), C(2), N(3)$, $\mathrm{N}(4)$

$$
\mathrm{Y}=\mathrm{S}^{c} \quad \mathrm{Y}=\mathrm{Se}^{c}
$$

Angles $\left({ }^{\circ}\right)$ between planes

$\begin{array}{rrrrr}(1)-(2) & 74.7 & 75.7 & 72.0 & 74.7 \\ (1)-(3) & 76.2 & 74.0 & 73.2 & 73.6 \\ (2)-(3) & 6.3 & 5.8 & 7.4 & 6.4\end{array}$

contd

value for complex $5,1.662(4) \AA$, is intermediate between these, in accord with the $3 c-4 e$ mode of bonding in tellurium(II) complexes. For Se-C in the $\mathrm{SeCN}^{-}$ion, the only reported value appears to be $1.829(25) \AA$ (in $\mathrm{KSeCN}$ ). ${ }^{20}$

Orientations of the ligands. The positions of the etu and tmtu ligands relative to the coordination plane are defined by the $\mathrm{Te}-\mathrm{S}-\mathrm{C}$ bond angle and by two dihedral angles: the tilt angle ${ }^{21}$ (here TeSX/TeSC or $\mathrm{TeS}_{2} / \mathrm{TeSC}$ ) and the twist angle ${ }^{21}$ (here $\mathrm{TeSC} / \mathrm{SCN}_{2}$ ). Similar parameters apply for the esu and tmsu ligands.

The Te-Se-C bond angles, at 95.1(2)-99.1(2) ${ }^{\circ}$, are smaller than the corresponding $\mathrm{Te}-\mathrm{S}-\mathrm{C}$ bond angles by $4.3(2)-4.5(1)^{\circ}$ for the esu and tmsu ligands and $2.2(2)^{\circ}$ for the $\mathrm{SeCN}$ ligands.

692
Table 6. (contd)

Distances $(\AA)$ of carbon atoms from thio- or selenourea plane $(3)^{a}$

$C(1), C(2) 0.002(2)-0.011(2)-0.001(3)-0.005(3)$

$\mathrm{C}(3), \mathrm{C}(5) \quad 0,027(2) \quad 0.095(2) \quad 0.042(4) \quad 0.118(3)$

$C(4), C(6) \quad 0.093(2)-0.070(2) \quad 0.106(4)-0.077(3)$

$\mathrm{Te}(\mathrm{tmtu})_{2}(\mathrm{SCN})_{2}$ and $\mathrm{Te}(\mathrm{tmtu})_{2}(\mathrm{SeCN})_{2}{ }^{b}$

Plane (1): Te, $Y(1), Y(2)$

Plane (2): Te, $Y(1), C(1)$

Plane (3): Te, $Y(2), C(2)$

Plane (4): $Y(2), C(2), N(2), N(3)$

$$
Y=S \quad Y=S e
$$

Angles $\left({ }^{\circ}\right)$ between planes

$\begin{array}{lll}(1)-(2) & 82.0 & 81.5 \\ (1)-(3) & 55.7 & 55.4 \\ (1)-(4) & 79.0 & 75.9 \\ (2)-(3) & 83.7 & 84.0 \\ (2)-(4) & 30.1 & 28.9 \\ (3)-(4) & 57.1 & 57.2\end{array}$

Distances $(\AA)$ of carbon atoms from thio- or selenourea plane $(4)^{a}$

$\begin{array}{lrr}C(2) & 0.003(3) & 0.007(6) \\ C(3) & -0.499(3) & -0.501(8) \\ C(4) & 0.739(3) & 0.742(7) \\ C(5) & -0.623(4) & -0.580(8) \\ C(6) & 0.445(4) & 0.428(8)\end{array}$

a Least-squares plane. ${ }^{b} Y(1)$ or $Y(2)$ as in Tables 4 and 5. ${ }^{c}$ Values for $Y(1)$ ligand on left, for $Y(2)$ ligand on right.

For the etu and esu ligands the tilt angles are 72.0-84.5 $5^{\circ}$ and the twist angles are 5.8-18.0 However, for the tmtu and tmsu ligands of complexes 5 and 6 the tilt angles are smaller and the twist angles are larger (see Table 6). The tmtu ligands in the four trans-Te(tmtu) $)_{2} \mathrm{X}_{2}$ complexes $^{2}$ referred to above are similarly oriented: for the eight tmtu groups, including the present one, the tilt angles are 42.3-61.7 (av. 55.2 ) and the twist angles are 52.7-62.8 (av. 57.0 $0^{\circ}$. The arrangement entails a close contact between the Te atom and one of the outer $\mathrm{CH}_{3}$ groups: $\mathrm{Te} \cdots \mathrm{C}_{\mathrm{Me}} 3.640$

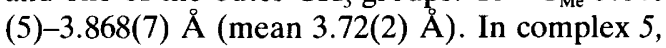
for which hydrogen positions were refined, the $\mathrm{Te} \cdots \mathrm{C}_{\mathrm{Me}}$ distance is $3.702(4) \AA$ and the shortest $\mathrm{Te} \cdot \mathrm{H}$ distances are 3.25(3) and 3.49(4) $\AA$. 
Table 7. Intermolecular contacts $(\AA)$ and angles $\left(^{\circ}\right)$ between $\mathrm{YCN}$ ligands ( $\mathrm{Y}=\mathrm{S}$ or $\mathrm{Se}$ ) across symmetry centre at $0,1 / 2,0$.

\begin{tabular}{lll}
\hline Complex & $Y \cdots Y$ & $Y \cdots Y-C$ \\
\hline $\mathrm{Te}(\mathrm{tmtu})_{2}(\mathrm{SCN})_{2}$ & $3.361(2)$ & $155.4(1)$ \\
$\mathrm{Te}(\mathrm{tmtu})_{2}(\mathrm{SeCN})_{2}{ }^{a}$ & $3.363(4)$ & $151.7(6)$ \\
$\mathrm{Te}(\mathrm{tmsu})_{2}(\mathrm{SeCN})_{2}$ & $3.398(1)$ & $152.0(2)$ \\
\hline
\end{tabular}

${ }^{a}$ Values calculated from atomic coordinates in Ref. 3.

Intermolecular contacts. In complexes 5 and 6 , close approaches occur between $\mathrm{S}$ or Se atoms of $\mathrm{SCN}$ or SeCN groups of neighbouring molecules. Data for these and for the third isomorph, Te $(\mathrm{tmtu})_{2}(\mathrm{SeCN})_{2},{ }^{3}$ are summarized in Table 7 . The NCS ...SCN and NCSe...SeCN systems are almost linear. The Se...Se distances of approach are comparable with the shortest intermolecular contacts in $\gamma$-Se $e_{8},{ }^{22}$ viz. 3.346(3) and 3.404(3) $\AA$.

Ionic environment in the salts. The $\mathrm{Cl}^{-}$ion lies 3.766(1) A from Te in complex 3 and 3.743(1) $\AA$ from $\mathrm{Te}$ in 4 ; the $\mathrm{Te} \cdots \mathrm{Cl}^{-}$axes make angles of 72.0 and $67.7^{\circ}$, respectively, with the $\mathrm{TeS}_{4}$ and $\mathrm{TeSe}_{4}$ planes. The $\mathrm{N}(1) \cdots \mathrm{Cl}^{-}$and $\mathrm{N}(3) \cdots \mathrm{Cl}^{-}$distances are 3.218(2) and 3.198(2) $\AA$, respectively, in complex 3 and $3.250(2)$ and 3.268(3) $\AA$ in 4 . These distances indicate $\mathrm{N}-\mathrm{H} \cdots \mathrm{Cl}^{-}$hydrogen bonds. The $\mathrm{Cl}^{-}$ion also partakes in hydrogen bonding to $\mathrm{N}(2)$ of the adjacent cation at $x, 1+y, z$, the $\mathrm{N}\left(2^{\prime}\right) \cdots \mathrm{Cl}^{-}$distance being $3.148(2)$ $\AA ̊$ in complex 3 and 3.147(2) $\AA$ in 4. The fourth nitrogen atom, $\mathrm{N}(4)$, has no $\mathrm{Cl}^{-}$ion closer than 4.006(2) $\AA$ in complex 3 and 3.976(3) $\AA$ in 4 .

The structure of $\left[\mathrm{Te}(\mathrm{dmtu})_{4}\right] \mathrm{Cl}_{2}\left(\mathrm{dmtu}=N, N^{\prime}\right.$ dimethylthiourea) has been determined by Barnard et al. ${ }^{23 a}$ In this salt, the shortest $\mathrm{Te}^{\cdots} \mathrm{Cl}^{-}$distance is $4.35 \AA$ and from the reported coordinates, ${ }^{23 a}$ this $\mathrm{Te}^{\cdots} \mathrm{Cl}^{-}$axis makes an angle of $76.2^{\circ}$ with the $\mathrm{TeS}_{4}$ plane. The authors ${ }^{23}$ discuss the state of hybridization of the lone $5 s$ and $5 p$ electron pairs of tellurium, and take the view that the large $\mathrm{Te}^{-\cdots \mathrm{Cl}^{-}}$distance accords with strong repulsion by $s p$ hybrid lone pairs. The $\mathrm{Te} \cdots \mathrm{Cl}^{-}$distances in the present salts, 3.766(1) and 3.743(1) $\AA$, are shorter and do not indicate strong repulsions. An ionic radius of $1.81 \AA$ for $\mathrm{Cl}^{-}$leaves 1.96 and $1.93 \AA$ for Te, both of which are less than the Pauling van der Waals radius ${ }^{24}$ of $2.20 \AA$ and also less than Bondi's value ${ }^{25}$ of $2.06 \AA$. Regarding the $\mathrm{Te}$ lone pairs, it may be noted that the $\mathrm{He}(\mathrm{I})$ photoelectron spectra of $\mathrm{TeBr}_{2}$ and $\mathrm{TeCl}_{2}$ can be satisfactorily interpreted in terms of $p$ orbitals alone $;^{26}$ the $5 s$ orbital of Te lies deeper than the $5 p$ orbitals.

Conformations of the $\left[\mathrm{Te}(\mathrm{etu})_{4}\right]^{2+}$ ion. The structure of the dihydrate, $\left[\mathrm{Te}(\mathrm{etu})_{4}\right] \mathrm{Cl}_{2} \cdot 2 \mathrm{H}_{2} \mathrm{O}$, has been reported by Elder et al. ${ }^{27}$ The tellurium atoms lie on two-fold symmetry axes, and the conformation of the cation, in the authors' notation, ${ }^{27}$ is +-+- ; the five-membered rings of neighbouring etu ligands lie alternately above and below the $\mathrm{TeS}_{4}$ plane. The authors ${ }^{27}$ suggest that this is the preferred geometry, interactions between neighbouring etu ligands thereby being avoided. However, in $\left[\mathrm{Te}(\mathrm{etu})_{4}\right]\left[\mathrm{TeCl}_{6}\right]^{28}$ the tellurium atoms also lie on two-fold axes and the geometry of the cation is not +-+- but ++-- . A molecular symmetry centre imposes ++-geometry, as in the present salt: neighbouring etu ligands lie on the same side of the $\mathrm{TeS}_{4}$ plane; however, there are no close contacts between the ligands, the shortest distances being $\mathrm{H}(1) \cdots \mathrm{H}(7)$ 2.95(3), $\mathrm{N}(3) \cdots \mathrm{H}(1) \quad 3.54(2)$ and $\mathrm{N}(1) \cdots \mathrm{H}(7)$ 3.64(2) A. In solution, rapidly established equilibria between conformers probably occur. Methanol dissolves $+-+-\left[\mathrm{Te}(\mathrm{etu})_{4}\right] \mathrm{Cl}_{2} \cdot 2 \mathrm{H}_{2} \mathrm{O}$, whereupon $++--\left[\mathrm{Te}(\mathrm{etu})_{4}\right] \mathrm{Cl}_{2}$ crystallizes. $^{5}$

\section{References}

1. Foss, O., Kjøge, H. M. and Marøy, K. Acta Chem. Scand. 19 (1965) 2349.

2. Foss, O. and Maartmann-Moe, K. Acta Chem. Scand., Ser. A 40 (1986) 675.

3. Åse, K., Foss, O. and Roti, I. Acta Chem. Scand. 25 (1971) 3808.

4. Foss, O. and Fossen, S. Acta Chem. Scand. 15 (1961) 1618.

5. Foss, O. and Fossen, S. Acta Chem. Scand. 15 (1961) 1620.

6. Foss, O. and Johannessen, W. Acta Chem. Scand. 15 (1961) 1941.

7. Klayman, D. L. and Shine, R. J. J. Chem. Soc., Chem. Commun. (1968) 372; J. Org. Chem. 34 (1969) 3549; Klayman, D. L. and Griffin, T.S. J. Am. Chem. Soc. 95 (1973) 197.

8. Foss, O. and Johannessen, W. Acta Chem. Scand. 15 (1961) 1940.

9. Cromer, D. T. and Waber, J. T. International Tables for X-Ray Crystallography, Kynoch Press, Bir- 


\section{FOSS ET AL.}

mingham 1974, Vol. 4, Table 2.2B; Cromer, D. T. Ibid. Table 2.3.1.

10. Wheatley, P. J. Acta Crystallogr. 6 (1953) 369; Battaglia, L. P., Corradi, A. B. and Nardelli, M. Croat. Chem. Acta 57 (1984) 545.

11. Vikane, O. Acta Chem. Scand., Ser. A29 (1975) 763.

12. Vikane, O. Acta Chem. Scand., Ser. A29 (1975) 787.

13. Fernholt, L., Samdal, S. and Seip, R. J. Mol. Struct. 72 (1981) 217.

14. Zvonkova, Z. V., Astakhova, L. I. and Glushkova, V.P. Kristallografiya 5 (1960) 547.

15. Hough, E. and Nicholson, D. G. J. Chem. Soc., Dalton Trans. (1981) 2083.

16. Spofford, W. A., Griffith, E. A. H. and Amma, E. L. J. Chem. Soc., Chem. Commun. (1970) 533; Griffith, E. A. H., Spofford, W. A. and Amma, E. L. Inorg. Chem. 17 (1978) 1913.

17. Anthoni, U., Borch, G., Larsen, S. and Nielsen, P. H. Unpublished work; cited by Larsen, S. and Henriksen, L. Acta Chem. Scand., Ser. A 38 (1984) 289.

18. Bats, J. W., Coppens, P. and Kvick, Å. Acta Crystallogr., Sect. B33 (1977) 1534; Bats, J.W. and Coppens, P. Ibid. p. 1542.
19. Dreizler, H., Rudolph, H. D. and Schleser, H. Z. Naturforsch., Teil A 25 (1970) 1643.

20. Swank, D. D. and Willett, R. D. Inorg. Chem. 4 (1965) 499.

21. Berta, D. A., Spofford, W. A., Boldrini, P. and Amma, E. L. Inorg. Chem. 9 (1970) 136.

22. Foss, O. and Janickis, V. J. Chem. Soc., Dalton Trans. (1980) 624.

23. (a) Barnard, P. W. C., Donaldsen, J. D., Grimsey, R. M. A., Dennes, G., Russo, U. and Calogero, S. Inorg. Chim. Acta 51 (1981) 217; (b) Calogero, S., Russo, U., Wagner, F. E. and Wordel, R. Ibid. 85 (1984) L51.

24. Pauling, L. The Nature of the Chemical Bond, 3rd ed., Cornell Univ. Press, Ithaca, New York 1960.

25. Bondi, A. J. Phys. Chem. 68 (1964) 441.

26. Jonkers, G., de Lange, C. A. and Snijders, J. G. Chem. Phys. 50 (1980) 11.

27. Elder, R. C., Marcuso, T. and Boolchand, P. Inorg. Chem. 16 (1977) 2700.

28. Ault, H. K. and Husebye, S. Acta Chem. Scand., Ser. A 32 (1978) 157.

Received July 18, 1986. 